\title{
HISTORY OF OPIUM IN SRI LANKA
}

by

\author{
C. G. URAGODA*
}

OPIUM figures in most pharmacopoeias of the East and the West, but its sinister reputation as a narcotic overshadows its medicinal properties. The British context has been examined in a recent book. ${ }^{1}$ In Sri Lanka, for centuries, it enjoyed unrestricted sales and uninhibited consumption like any other article of commerce. It was not till the middle of the last century that the public became alive to its baneful effects. In response to public protests, the state placed progressively tighter restrictions on the sale and use of opium.

Opium was native to West Asia, which included Persia and Afghanistan. It was known to the Greeks as early as the third century BC, and they were credited with having discovered its narcotic properties. It was introduced to the East largely by Arab traders, and was known to the Chinese by the ninth century AD. Indians learned of its medicinal properties probably through Arab physicians who came to India with the Mohammedan conquerors in the twelfth century AD. ${ }^{2}$

\section{EARLY HISTORY}

In Sri Lanka, opium has been used in Ayurvedic medicine during the last few centuries. The earliest reference to its medicinal properties is in Yogaratnakara, an Ayurvedic book written in Sinhala verse in the sixteenth century. ${ }^{3}$

There is no evidence that the poppy was ever grown in Sri Lanka, and, being an island, all the opium would therefore have been imported. In tracing the history of opium, it is relevant to mention that Sri Lanka was under the successive administrations of the Portuguese (1517-1656), the Dutch (1656-1796), and the British (1796-1948). The Portuguese and the Dutch were able to capture only the maritime provinces, the central mountainous region being under the control of the kings of Kandy. However, in 1815, the British annexed the Kandyan kingdom too, and thereby governed the entire country.

De Queyroz, the Portuguese historian, mentions that during the Portuguese occupation opium was imported by the king of Kandy, the point of entry being Cotiar near Trincomalee, which was part of the Kandyan kingdom at the time. ${ }^{4}$

${ }^{*}$ C. G. Uragoda, MD, FRCP, FCCP, AFOM, Physician-in-charge, Central Chest Clinic, Colombo 10, Sri Lanka.

${ }^{1}$ Virginia Berridge and Griffith Edwards, Opium and the people: opiate use in nineteenth-century England, London, Allen Lane; New York, St Martin's Press, 1982. See also, Terry M. Parssinen's essay review of this book in Med. Hist., 1982, 26: 458-463.

2 John Attygalle, Sinhalese materia medica, Colombo, Colombo Apothecaries' Co., 1917, p. 10.

${ }^{3}$ Ibid., p. 10.

4 Father Fernao de Queyroz, The temporal and spiritual conquest of Ceylon, trans. by Father S. G. Perera, Colombo, Acting Government Printer (Ceylon), 1930, p. 65. 


\section{G. Uragoda}

The importation of opium during the Dutch period is substantiated by Governor Ryckloff Van Goens ${ }^{3}$ in his memoirs written in 1663 and left for the benefit of his successor. He mentions that opium was imported from Surat and Bengal in India.

\section{CUSTOMS DUTIES}

As soon as the British East India Company took over the administration of Ceylon, as Sri Lanka was then known, all import duties were suspended except those on arrack (a spirit distilled from the coconut palm), and opium. ${ }^{6}$ A customs duty of 20 rixdollars or $22 \frac{1}{2}$ rupees per pound of imported opium was levied. This was a considerable amount at that time. Some years later it was reduced to 5 rixdollars, and by 1840 to one shilling per pound. In 1885 , the import duty was fixed at 1 rupee per pound, in 1897 it was raised to 2 rupees, and again in 1907 to 4 rupees per pound.' These rates of duty were considered heavy, and resulted in an increase in smuggling. The authorities viewed this smuggling as a loss of revenue rather than a danger to the public.

The growth of the opium trades is shown in Table 1. The total consumption of opium in the country was probably much higher, if the quantity smuggled is taken into consideration. Smuggling took place not only from the established ports but also from minor ones such as Kalmunai on the east coast.9

TABLE 1. THE GROWTH OF THE OPIUM TRADE

$\begin{array}{lc}\text { Year } & \text { Pounds of opium imported } \\ 1840 & 1,562 \\ 1850 & 852 \\ 1860 & 8,379 \\ 1870 & 12,449 \\ 1880 & 10,117 \\ 1890 & 12,807 \\ 1900 & 23,755\end{array}$

At the beginning of the century, opium was imported in the form of balls. The drug itself was semi-liquid and of the consistency of treacle. It was covered with a hard shell of leaves that resembled the rind of a cheese ball.

\section{THE OPIUM HABIT}

Opium was ostensibly imported into the country as a drug. It was widely prescribed in Ayurvedic medicine, at least in the nineteenth century, for the alleviation of pain and induction of sleep. This was the manner by which the majority of opium addicts first came into contact with the drug.

\footnotetext{
' Ryckloff Van Goens, Selections from the Dutch records of the Ceylon government, No. 3: Memoirs of Ryckloff Van Goens 1663-1675, trans. by E. Reimers, Colombo, Ceylon Government Press, 1932, p. 2.

- Colvin R. de Silva, Ceylon under the British occupation, Colombo, Colombo Apothecaries' Co., 1942, vol. 2, p. 445.

'Sessional Paper 5, Despatches regarding the consumption of opium in Ceylon, Colombo, Government Printer (Ceylon), 1908, p. 2.

Ibid., p. 7.

Ibid., p. 7.
} 


\section{History of opium in Sri Lanka}

In the early British period, opium was freely peddled by itinerant traders with tobacco and curry powders. It is on record that in 1834 a police sergeant went on a historic mission disguised as an itinerant opium-seller. He was sent to investigate a rumour that a Kandyan chieftain, the First Adigar Molligoda, was involved in a plot to poison the Governor and the principal officials at a banquet, to corrupt the Malay troops, and with their assistance to destroy the English garrison and so re-establish the independence of the Kandyan kingdom. ${ }^{10}$

The free availability of opium was no doubt responsible for the escalating consumption shown in Table 1. However, the first official frowns on the habit appeared quite early in the nineteenth century. In 1806 and 1807, the Governor, Sir Thomas Maitland, enacted a series of regulations aimed at combating lawlessness. One of these prohibited the smoking of opium in Colombo after sunset without permission from the constable of the division. ${ }^{11}$

Certain communities appeared to have succumbed to the opium habit more than others. Large quantities of opium were imported into China during the last century (see below), and Sri Lanka figured in an incident which underlined this vast traffic. In June 1857, during a squall, the P. \& O. liner, Erin struck a sand bank and sank at the mouth of the river Kaluganga, thirty miles south of Colombo. She was carrying, among other goods, a consignment of opium worth $£ 170,000$ to China from Bombay. This was an enormous sum of money, and the entire consignment was lost. ${ }^{12}$

It was observed by Major Thomas Skinner, the famous road-builder of the last century, that the consumption of opium among the Malay troops in the British army in Ceylon was high. They were held in high esteem by the British authorities, but the use of opium rendered them unfit for service at an early age. ${ }^{13}$

\section{OPIUM SHOPS}

A novel feature of the history of opium distribution in Sri Lanka was the system of licensed opium shops that existed in the second half of the last century. Ordinance No. 19 of 1867 , entitled "An ordinance to prohibit the sale of opium and bang except by duly licensed persons", permitted the opening of opium shops under licence from the government. The bill was referred by the Legislative Council of Ceylon on 13 November 1867 to a sub-committee headed by R. F. Morgan, Queen's Advocate (the equivalent of the Attorney-General today). The sub-committee reported "that the ordinance will prove useful in restricting the use of opium and bang (ganja or hashish), and giving the police due surveillance of the places where they are consumed."14 However, these intentions were not fulfilled, for opium consumption increased, probably helped by its free availability in opium shops.

In the middle of the last century, opium was used as security for obtaining money on loan. Chettiars, a race of merchant bankers from South India, had in their custody

\footnotetext{
${ }^{10}$ G. K. Pippet, A history of the Ceylon police, Vol. 1: 1795-1870, Colombo, The Times of Ceylon Co., 1938 , p. 155.

11 Ibid., p. 33.

12 Ibid., p. 141.

13 Ibid., p. 146.

14 Sessional Paper 11, Sale of opium and bang, Colombo, Government Printer (Ceylon), 1867, p. 2.
} 


\section{G. Uragoda}

large stocks of opium that had been pledged to them by the opium dealers. This aspect was taken into consideration in drafting the ordinance. It prohibited the possession of more than two pounds of opium without a licence. ${ }^{15}$

Opium was widely prescribed as a medicine by both the qualified western and Ayurvedic practitioners. In the absence of any legal provision concerning medical qualifications in the country, the sub-committee was not prepared to restrict the sale of opium to any particular class of medical practitioners. ${ }^{16}$

Opium shops were opened even before legislation was enacted in 1867. The first such shop was in Chilaw, and it was in existence in 1850. A second shop was opened about 1860 in Hambantota, a small town with a considerable Malay population. The number of shops rapidly increased after 1867 , there being thirty-one in 1890 , fifty-six in 1897 , and sixty-five in $1907 . .^{17}$

The revenue from these shops was considerable. The licence fees from the shops in the villages went to the government; this amounted to Rs.4,100 in 1893. In 1906, it increased to Rs.69,119. The Municipalities and Local Boards received the revenue from shops in cities and towns; it increased from Rs.37,360 in 1893 to Rs.122,189 in 1907. ${ }^{18}$

Opium shops were subject to several conditions. The hours of business were restricted to $6 \mathrm{a} . \mathrm{m}$. to $8 \mathrm{p} . \mathrm{m}$., and the maximum quantity that could be sold to an individual was 180 grains. The sale of opium to women and children under fifteen years of age was prohibited. Cigars were the only other items that were permitted to be sold in these shops. Bartering of opium in exchange for other goods was prohibited. ${ }^{19}$

At first, consumption of opium within the premises of the licensed shop was allowed. An opium "den" was attached to the shop where opium was smoked by the consumers, who paid a monthly rental, usually a rupee. Subsequently, this practice was prohibited. This step may not have had the desired effect of restricting the use of opium, for the customers by taking it home exposed others to the habit. ${ }^{20}$ It may be mentioned that according to official returns the number of habitual users of opium in the country in 1908 was $19,847.21$

The wishes of the people were not consulted in opening opium shops. There was no evidence that a request was ever made by Sinhala or Tamil villagers to have an opium shop in their midst. In fact, Buddhists condemned the use of the drug.

\section{AGITATION}

In December 1893, a large public meeting was held in Colombo to agitate for sanctions in the sale of opium. It was attended by representatives of all races and classes and it adopted a memorial to the Legislative Council. The extent of public opposition

is Ibid., p. 2.

16 Ibid., p. 2.

${ }^{17}$ Sessional Paper 5, op. cit., note 7 above, p. 2.

18 Ibid., p. 3.

19 Sessional Paper 19, Correspondence relating to the sale of opium, Colombo, Government Printer (Ceylon), 1903, p. 6.

${ }^{20}$ Sessional Paper 5, op. cit., note 7 above, p. 7.

${ }^{21}$ Ibid., p. 17. 


\section{History of opium in Sri Lanka}

to the government's policy on opium was shown by the number who signed this memorial. The signatories, who were confined to those who could write, comprised 13,957 Sinhala, 11,878 Tamils, 1,265 Burghers, 265 Europeans, and 465 of other nationalities. 22

No action was taken on this memorial from 1894 to 1896. In 1897, the Governor, Sir West Ridgeway, by an ordinance doubled the duty on opium from Rs.1 to Rs. 2 per pound and banned the import of bang or ganja. In 1898, he appointed a select committee, which reported that the opium habit had spread among the people to a remarkable degree. The committee unanimously recommended that no further opium shops be opened except with the express sanction of the government. The number of opium shops increased despite this restriction. ${ }^{23}$

The opposition to the government policy on opium was spearheaded by the Rev. Hikkaduwe Sri Sumangala, a leading figure in the Buddhist renaissance, and $\mathrm{Mr}$ S. C. Obeyesekere, a member of the Legislative Council. The condemnation of the government policy reached the ears of British parliamentarians. In 1902, Mr W. S. Caine, MP, asked the Secretary of State for the Colonies in the House of Commons, "Whether he is aware that the importation of opium into Ceylon last year was $21,005 \mathrm{lb}$., in $189512,827 \mathrm{lb}$., in $188010,116 \mathrm{lb}$., while in 1870 it was only 2,499 , thus increasing over eight-fold in thirty years; and whether he will order an inquiry into the causes of this increase, with a view to its abatement?". The Secretary of State for the Colonies, The Rt Hon. Joseph Chamberlain, MP, replied: "The figures quoted appear to be correct, except for the year 1870, when the imports amounted to 12,449 and not $2,499 \mathrm{lb}$. I will ask the Governor of Ceylon to make inquiry into the causes of any increase." 24

A few years later, another question was asked in the House of Commons. Dr Rutherford, MP, directed a searching question at the Under-Secretary of State for the Colonies on 15 April 1907. He asked "whether Sinhalese people grew the poppy in Ceylon or used opium under their native kings, or during the Portuguese or Dutch rule, or until the middle of last century, when the British Government established licensed shops for the sale of opium in towns and villages; and whether, seeing that the importation of opium has increased from $1,000 \mathrm{lb}$. in 1850 to $20,000 \mathrm{lb}$. in 1905, and that the Buddhist High Priest Sumangala and the Sinhalese representative on the Legislative Council, Mr Obeyesekere, have appealed to the Government to close the licensed shops, His Majesty's Government will take steps to suppress the opium traffic in Ceylon?".

Winston Churchill, holding his first government office, in answering the question said that he could not "dispute nor confirm the facts which the Honourable Member has assembled; but the increase of imports of opium into Ceylon under British rule has already formed the subject of official inquiry and correspondence, and is engaging the serious attention of the Secretary of State". ${ }^{2 s}$

This question turned out to be the catalyst for a chain of events that radically

22 Ibid., p. 2.

${ }^{23}$ Ibid., p. 2.

24 Sessional Paper 19, op. cit., note 19 above, p. 3.

${ }^{2 s}$ Sessional Paper 5, op. cit., note 7 above, p. 1. 


\section{G. Uragoda}

changed government policy on opium. A few days later, the Secretary of State for the Colonies, the Earl of Elgin and Kincardine, wrote to the Governor, Sir Henry A. Blake, expressing the view that the importation of increasing quantities of opium into Ceylon could not be defended. He suggested the appointment of a committee. Accordingly, the Governor appointed a committee headed by Sir Allan Perry, Principal Civil Medical Officer, and including $\mathrm{Mr}$ S. C. Obeyesekere. It recommended far-reaching reforms in the sale and use of opium. The main recommendations were (a) that all opium shops be closed; (b) that the importation, distribution, and sale of opium be made a government monopoly; and (c) that opium for medicinal use and for addicts be sold by government dispensaries. These recommendations were accepted by the Governor and approved by the Secretary of State. The government decided to compensate the Municipalities and Local Boards which would lose revenue by the closure of the licensed shops. ${ }^{26}$

\section{CULTURAL BACKGROUND}

The agitation against the opium policy of the government which started in the latter part of the nineteenth century had cultural and religious undertones. It was a time when the local population was demanding increased representation and a bigger voice in the Legislative Council. The Buddhists, who comprised over seventy per cent of the population, resented the relegated status given to their religion under an alien government. This resentment gradually developed into a movement for the revival of Buddhism. One of the five precepts of the religion was abstinence from intoxicating liquor. Therefore, as a corollary to the Buddhist revival a temperance movement aimed at the excise policy of the government began to take shape. Though the use of opium was not specifically denied to Buddhists, it was natural that a substance imported by the British with a profit motive and which induced much depravity in the people should be condemned as much as or more than alcohol. This attitude was shared by other religions in the country, and the agitation against opium found common support among all the races, as shown by the numbers that signed the memorial to the Legislative Council.

\section{INTERNATIONAL TRADE}

In the eighteenth and nineteenth centuries, the biggest supplier of opium to the east was India, and the largest consumer, China. The opium habit in China spread rapidly when, shortly after the introduction of tobacco in the early seventeenth century, it was mixed with pipe tobacco and smoked. On the other hand, the habit did not find such ready dissemination in Sri Lanka, where the first contact with opium was invariably as an Ayurvedic drug in times of illness.

The Indian opium trade, which was in the hands of the Portuguese, passed to the British East India Company in 1773. At the beginning of its administration of Ceylon, the Company imposed an import duty on only two products, one of which was opium. This policy was probably dictated by the prospect of making a considerable profit margin, as the Company controlled the export of opium in India.

\footnotetext{
26 Ibid., pp. 19, 20.
} 


\section{History of opium in Sri Lanka}

The importation of opium into China was banned by the Chinese emperor in 1796. However, illicit smuggling into China from British depot ships carrying opium from India continued. ${ }^{27}$ In 1839, this conflict between Britain and China led to open war that ended in the cession of Hong Kong to the British. ${ }^{23}$ After the treaty of Nanking (1842), the importation of opium into China was legalized in 1858. Thereafter, imports increased considerably while at the same time opium was grown extensively in China. Still India supplied one-seventh of the total opium consumed in China. In 1906, it was estimated that twenty-seven per cent of adult males in China smoked opium. In that year, the Chinese, regarding opium addiction as one of the most acute moral and economic questions, decided to put an end to the drug's use within ten years.

In 1906, the American government in the Philippines, perturbed by the opium trade there, raised the question of joint action by interested powers for its suppression. As a result, delegates from several countries including China, USA, and UK met in Shanghai in 1907.29 This conference, the first international one on the control of opium, resolved that respective governments should prevent the export of opium to countries prohibiting its importation.

These international developments were echoed in Sri Lanka. The upward trend in the importation of opium, which began in the 1850s (Table 1), came in the wake of the opium war that resulted in the uninhibited importation of the drug into China. The opium imported to Sri Lanka came from India. The policy in India at the time was one of free cultivation, but the cultivator was required to sell his produce to the government. Opium cultivation was a profitable agricultural venture, and its extent in India may be gauged from the magnitude of trade with China, which in 1880 amounted to over twelve million pounds. The Indian government, obliged to buy large stocks of opium from cultivators, would have looked for other countries to push its exports, and neighbouring Sri Lanka would have been an obvious choice.

The international agitation against forcing opium on uninterested countries started in 1906, and in 1907 Dr Rutherford directed his question in the House of Commons. It is likely that the international climate, which favoured controls on the export of opium, influenced the British government to react favourably in curtailing the opium trade to Sri Lanka.

\section{PRESENT POSITION}

Government policy on opium has changed little since reforms were introduced over seventy years ago. The entire requirement of the country is imported by the Superintendent of the State Medical Stores, who is also the Chief Opium Officer. Raw opium is issued only to registered Ayurvedic practitioners on a permit issued by the Government Agent of the district after the application has been duly investigated

\footnotetext{
${ }^{27}$ Encyclopaedia Britannica, 11 th ed., Cambridge University Press, 1911, p. 130.

28 Brian Inglis, The opium war, London, Hodder \& Stoughton, 1976; J. Beeching, The Chinese opium wars, London, Hutchinson, 1975; Peter Ward Fay, The opium war 1840-42. Chapel Hill, University of North Carolina Press, 1975.

${ }^{29}$ Encyclopaedia Britannica, loc. cit., note 27 above.
} 


\section{G. Uragoda}

by the police. Addicts are no longer provided with opium. The drug is issued by the respective District Hospitals.

These measures have succeeded in reducing the importation of opium, all of which still com 's from India, to an average of $150 \mathrm{~kg}$. a year. This figure does not include the amount smuggled into the country. When smuggling is detected, the opium is confiscated and then quality-tested. If it conforms to British Pharmacopoeia Standards, it is taken over by the State Medical Stores to supplement its stock.

\section{SUMMARY}

Opium has been imported into Sri Lanka for several centuries. During the latter part of the last century, there was a steep rise in its consumption, one of the main reasons being the free availability of the drug in licensed opium shops. A question asked in the House of Commons in 1907 triggered off a chain of events which finally led to far-reaching reforms in government policy, including the closure of opium shops. The agitation against opium in the country coincided with a Buddhist revival. The events in Sri Lanka were influenced by international trends, particularly those in India and China. Since the introduction of reforms over seventy years ago, the legitimate importation of opium has declined to insignificant levels. The government policy on opium has remained almost unchanged to the present day.

I wish to thank Prof. Ralph Pieris, Professor of Sociology, University of Colombo, and Mr K. W. A. Jayawardane, Librarian, Sri Lanka Medical Library, for their assistance. 